\title{
POLA-POLA KOMUNIKASI NELAYAN DALAM MEWUJUDKAN KETAHANAN PANGAN RUMAHTANGGA NELAYAN DI KOTA BENGKULU (Kasus pada Nelayan Kapal Kecil)
}

\author{
Fishermen Communication Patterns in Constructing \\ The Fishermen Household Food Security in Bengkulu City \\ (Case in Small Boat Fishermen)
}

Gita Mulyasari dan Nyayu Neti Arianti

Jurusan Sosial Ekonomi Pertanian Fak. Pertanian Universitas Bengkulu gita_mulyasari@yahoo.co.id

\begin{abstract}
Some earlier results showed that there were $43 \%$ of the families belonging to the famine did not get help from the local community when food shortages. By looking at these conditions, this study was designed to examine how fishermen communication patterns in their interaction with the social environment in order to achieve food security in the household. Respondents were drawn from a group of fishermen called the Kelompok Usaha Bersama (KUB) in Pulau Baai. From an interview with the head of a group of fishermen, the number of fishermen using small boats is 24 households. This research results showed there were two fishermen communication patterns in discussing household food security issues, namely, the interpersonal communication and group communication. Interpersonal communication patterns involving informations from other fishermen. Messages are widely discussed is everything associated with their fishing fishing effort. Among the existing group communication, group discussion fishermen have an impact on the fishing action in carrying out their fishing effort. Advances in fishery business can increase revenue and will also have an impact on the family's food security.
\end{abstract}

Keywords: fishermen, communication pattern, food security

\section{PENDAHULUAN}

Pangan merupakan hal penting yang harus dipenuhi oleh setiap manusia untuk keberlangsungan hidupnya. Pangan yang dimaksud dalam hal ini adalah pangan pokok bagi masyarakat Indonesia, yaitu beras, sumber karbohidrat bagi tubuh. Tercukupinya asupan gizi yang terkandung dalam pangan dan diserap oleh tubuh dapat menghasilkan sumber daya manusia yang berkualitas. Mengingat pentingnya memenuhi kecukupan pangan, maka setiap negara akan mendahulukan pembangunan ketahanan pangannya sebagai fondasi bagi pembangunan sektor-sektor lainnya (Arumsari dan Rini, 2007).

Gita Mulyasari dan Nyayu Neti Arianti. Pola-Pola Komunikasi Nelayan... |53 
Oleh karena itu, Indonesia berkomitmen untuk mewujudkan ketahanan pangan dan hal tersebut dituangkan dalam Undang-Undang Nomor 7 tahun 1996 tentang pangan.Undang-Undang tersebut mendefinisikan ketahanan pangan sebagai suatu kondisi terpenuhinya pangan bagi rumahtangga yang tercermin dari tersedianya pangan yang cukup dalam jumlah maupun mutunya, aman, merata, dan terjangkau.Berdasarkan definisi tersebut, ketahanan pangan yang dimaksud tidak hanya di tingkat global, nasional, dan regional tapi juga sampai pada tingkat rumahtangga.

Ketersediaan pangan nasional dan regional tidak menjamin adanya ketahanan pangan rumahtangga atau individu karena ketersediaan pangan dan ketahanan pangan ditentukan oleh akses untuk mendapatkan pangan (Saliem et al., 2005). Dampak dari ketiadaan akses terhadap pangan salah satunya seperti yang terjadi di Indonesia, yaitu krisis pangan di Yahukimo, Papua yang mengakibatkan terjadinya kasus kelaparan besar- besaran.

Ketahanan pangan merupakan suatu sistem yang terdiri dari atas subsistem ketersediaan dan distribusi pangan serta subsistem konsumsi.Ketersediaan dan distribusi memfasilitasi pasokan pangan yang stabil dan merata ke seluruh wilayah, sedangkan subsistem konsumsi memungkinkan setiap rumahtangga memperoleh pangan yang cukup dan memanfaatkannya secara bertanggung-jawab untuk memenuhi kebutuhan gizi seluruh anggota keluarganya (Suryana, 2004).

Status gizi masyarakat merupakan hasil lanjutan (outcome) ketahanan pangan rumahtangga.Keadaan gizi setiap individu sangat dipengaruhi oleh asupan bahan pangan yang dikonsumsi, yang ditentukan oleh kemampuan penyediaan dan pengelolaan konsumsi pada masing-masing rumahtangga.

Jika ditinjau dari karakteristik masyarakat, bahwa karakteristik masyarakat pesisir berbeda dengan karakteristik masyarakat agraris seiring dengan perbedaan karakteristik sumber daya yang dihadapinya, dimana masyarakat agraris menghadapi sumber daya yang terkontrol yaitu pengelolaan lahan untuk produksi suatu komoditas dengan output yang dapat diprediksi sedangkan karakteristik masyarakat nelayan menghadapi sumber daya yang hingga saat ini masih bersifat open access.

Pendapatan rumahtangga nelayan penuh dengan ketidakpastian. Menurut Kusnadi (2000), pada rumahtangga nelayan buruh, persoalan mendasar yang dihadapi oleh rumahtangga nelayan buruh yang tingkat penghasilannya kecil dan tidak pasti adalah bagaimana mengelola sumber daya ekonomi yang dimiliki secara efisien dan efektif sehingga mereka bisa "bertahan hidup" dan bekerja. Kelompok-kelompok yang berpenghasilan rendah lebih berorientasi pada pemenuhan kebutuhan pokok pangan dalam upaya kelangsungan kehidupan rumahtangganya.

Struktur perekonomian Kota Bengkulu didominasi oleh sektor pertanian khususnya subsektor perikanan. Kontribusi subsektor ini masih 
cukup besar yaitu mencapai 70\%. Meskipun perikanan tersebut merupakan subsektor unggulan yang memberikan kontribusi cukup signifikan terhadap PDRB Kota Bengkulu, namun sangat disayangkan bahwa pelaku ekonomi terutama nelayan masih berada di bawah garis kemiskinan.

Fakta riil menunjukkan bahwa tingkat kesejahteraan masyarakat nelayan Kota Bengkulu relatif lebih rendah dibandingkan sektor di luar perikanan. Mayoritas masyarakat nelayan di pesisir Kota Bengkulu berada pada kategori Keluarga Prasejahtera dan Keluarga Sejahtera I sebesar 15\% dari jumlah penduduk. Studi tentang kemiskinan masyarakat nelayan yang dilakukan oleh Satria (2002) dan Kusnadi (2000) menyimpulkan paling tidak ada sepuluh faktor penyebab kemiskinan masyarakat nelayan antara lain kemiskinan karena faktor alam, budaya dan kebijakan pemerintah.

Berdasarkan hasil penelitian Tanziha (2005), pada aras mikro hasil penelitian menunjukkan bahwa determinan utama kelaparan adalah kemiskinan, dan determinan lingkungannya adalah rendahnya kepedulian dari masyarakat setempat, serta sangat kurangnya atau bahkan tidak ada kelembagaan ketahanan pangan ditingkat masyarakat. Hasil penelitian menunjukkan bahwa ada $43 \%$ keluarga yang tergolong kelaparan tidak mendapat bantuan dari masyarakat setempat saat kekurangan pangan. Dengan melihat kondisi ini, maka penelitian ini dirancang untuk melihat bagaimana pola komunikasi nelayan dalam berinteraksi dengan lingkungan sosialnya agar dapat mewujudkan ketahanan pangan dalam rumahtangganya.

Penelitian ini bertujuan untuk mengetahui dan mendeskripsikan pola komunikasi nelayan dalam upaya mencapai ketahanan pangan rumahtangganya. Ketahanan pangan merupakan kondisi tersedianya pangan yang memenuhi kebutuhan setiap orang setiap saat untuk dapat hidup sehat, aktif, dan produktif.

\section{METODE PENELITIAN}

Penelitian ini menggunakan metode dasar deskriptif yaitu suatu metode yang digunakan untuk menemukan pengetahuan yang seluas-luasnya terhadap objek penelitian pada suatu saat tertentu dengan maksud untuk mengumpulkan informasi mengenai status suatu variabel atau tema, gejala atau keadaan yang ada, yaitu keadaan gejala menurut apa adanya pada saat penelitian dilakukan (Widodo dan Mukhtar, 2000). 
Penelitian dilaksanakan di Kelurahan Pulau Baai Kecamatan Kampung Melayu Kota Bengkulu. Kajian yang dibahas adalah berkenaan dengan pola komunikasi nelayan dalam memenuhi kebutuhan rumahtangganya untuk mewujudkan ketahanan pangan rumahtangganya.

Responden dalam penelitian ini merupakan para nelayan kapal kecil. Nelayan kapal kecil adalah nelayan yang bekerja sendiri, nelayan kapal kecil tidak mempunyai anak buah kapal atau juru mudi kapal. Nelayan kapal kecil masih menggunakan alat tangkap yang sederhana seperti jaring, rawai dan pancing. Mesin yang mereka punya juga terbilang kecil menyesuaikan kapal mereka yang kecil. Bobot kapal nelayan kapal kecil hanya berkisar antara 1 hingga 3 GT (Gross Tonnage). Responden nelayan akan diambil dari kelompok nelayan dalam Kelompok Usaha Bersama (KUB) di Pulau Baai yang ditentukan menggunakan metode sensus, dimana seluruh populasi diselidiki tanpa terkecuali. Dari wawancara dengan ketua kelompok nelayan, jumlah nelayan yang menggunakan kapal kecil sebanyak 24 orang.Mereka tersebar di 5 kelompok nelayan. Responden penelitian diambil dari kelompok nelayan pada usaha perikanan tangkap di Pulau Baai dapat seperti tertera pada Tabel 1.

Tabel 1. Kelompok Nelayan Usaha Perikanan Tangkap di Kelurahan Pulau Baai

\begin{tabular}{lcc}
\hline $\begin{array}{c}\text { Nama Kelompok } \\
\text { Nelayan }\end{array}$ & $\begin{array}{c}\text { Jumlah Anggota } \\
\text { Kelompok Nelayan }\end{array}$ & $\begin{array}{c}\text { Jumlah Nelayan Kapal } \\
\text { Kecil (Responden } \\
\text { Penelitian) }\end{array}$ \\
\hline Ambai-Ambai & 10 & 4 \\
Tenggiri & 12 & 5 \\
Camar Bahari & 10 & 5 \\
Bengkulu Serikat & 10 & 5 \\
Lumba-Lumba & 10 & 5 \\
\hline Jumlah & 52 & 24 \\
\hline
\end{tabular}

Sumber: Data Primer Diolah, 2014

Jenis penelitian ini adalah penelitian deskriptif yaitu mencermati fenomena sosial tertentu dengan mengembangkan konsep dan menghimpun fakta, tanpa menguji hipotesa.

Strategi yang digunakan adalah studi kasus tunggal, karena penelitian hanya dilakukan pada satu satu sasaran (satu desa) dan sasaran penelitian ini memiliki karakteristik yang sama yaitu tingkat sosial ekonomi yang sama. Data dan informasi yang dikumpulkan dan dikaji sebagian besar berupa data kualitatif. Adapun sumber data dalam penelitian ini adalah informan. Teknik pengumpulan data dilakukan dengan cara wawancara mendalam dan observasi. Model analisis yang digunakan adalah analisis interaktif yang terdiri dari tiga komponen yaitu reduksi data, sajian data dan penarikan simpulan dan verifikasi. 


\section{HASIL DAN PEMBAHASAN}

Masyarakat pesisir memiliki kehidupan yang khas, dihadapkan langsung pada kondisi ekosistem yang keras, dan sumber kehidupan yang bergantung pada pemanfaatan sumber daya pesisir dan laut. Masyarakat pesisir terutama nelayan kecil, masih terbelit oleh persoalan kemiskinan dan keterbelakangan. Ketahanan pangan merupakan Hak Asasi Manusia (HAM). Setiap orang berhak memperoleh makanan yang layak dan sesuai dengan kebutuhannya. Kemiskinan yang dialami oleh nelayan akan memberikan dampak buruk salah satunya pada masalah pemenuhan kebutuhan konsumsi pangan. Jika kebutuhan konsumsi pangan tidak terpenuhi lagi maka akan menimbulkan kerawanan pangan (food insecurity). Keadaan ini pada akhirnya akan mempengaruhi status gizi rumahtangga nelayan.

Pola komunikasi merupakan cara berkomunikasi satu sama lain dalam suatu masyarakat yang telah menjadi kebiasaan dan dilakukan secara berulang-ulang. Komunikasi terjadi sebagai konsekuensi hubungan sosial (social relations).Untuk menimbulkan sebuah komunikasi paling sedikit dibutuhkan dua orang yang saling berhubungan satu sama lain dan menimbulkan suatu interaksi sosial.

Berikut pola komunikasi nelayan di Kota Bengkulu yang disajikan dalam tiga pola komunikasi yaitu: komunikasi interpersonal, komunikasi kelompok dan komunikasi massa. Pola-pola komunikasi tersebut merupakan cara-cara berkomunikasi nelayan di Kelurahan Pulau Baai Kecamatan Kampung Melayu Kota Bengkulu dalam memperbincangkan usaha perikanan tangkapnya untuk ketahanan pangan rumahtangga mereka.

\section{Pola Komunikasi Interpersonal}

Pola komunikasi interpersonal nelayan melibatkan beberapa sumber informasi terdekat secara fisik maupun psikologis, seperti orang tua, kerabat, saudara, dan tetangga yang sama-sama bekerja sebagai nelayan. Dengan sumber-sumber ini mereka saling bertukar informasi (pesan) pengalaman baik pengalaman usaha perikanan tangkapnya maupun pengalaman tentang lingkungan sekitar. Bila diuraikan, unsur-unsur komunikasi yang terlibat dalam pola komunikasi interpersonal tertera dalam Tabel 2.

Pada pola komunikasi interpersonal yang dilakukan oleh nelayan, lebih banyak melibatkan sumber informasi dari nelayan lain. Pesan yang banyak diperbincangkan adalah segala sesuatu yang berkaitan dengan usaha perikanan tangkapnya. Saluran komunikasi yang digunakan adalah saluran interpersonal dalam percakapan setiap kali mereka bertemu dengan orang lain. Arus informasi yang terjadi dalam pola komunikasi interpersonal adalah dua arah (timbal balik), sumber (komunikator) dan penerima (komunikan) secara langsung saling berganti peran. 
Orangtua merupakan sumber terdekat di antara sumber-sumber tersebut dalam memberikan informasi dalam usaha perikanan tangkap yang dilakukan oleh nelayan. Ada beberapa pengetahuan yang diturunkan oleh orangtua mereka yang sebelumnya juga berprofesi sebagai nelayan. Selain dengan orang-orang terdekat, mereka juga terlibat dalam komunikasi interpersonal dengan pedagang ikan yang terdapat di Tempat Pelelangan Ikan (TPI). Negosiasi harga yang dilakukan antara nelayan dan pedagang menjadi alat nelayan untuk mendapatkan penerimaan yang lebih baik. Penerimaan ini digunakan untuk mencukupi kebutuhan pangan dalam keluarganya.

\section{Tabel 2. Unsur-unsur Komunikasi dalam Pola Komunikasi Interpersonal Nelayan di Kota Bengkulu}

\begin{tabular}{|c|c|c|c|}
\hline $\begin{array}{l}\text { Sumber } \\
\text { (Source) }\end{array}$ & Pesan (Message) & $\begin{array}{l}\text { Saluran } \\
\text { (Channel) }\end{array}$ & $\begin{array}{l}\text { Komunikan } \\
\text { (Receiver) }\end{array}$ \\
\hline $\begin{array}{l}\text { Orang tua, } \\
\text { kerabat, dan } \\
\text { tetangga yang } \\
\text { bekerja } \\
\text { sebagai } \\
\text { nelayan }\end{array}$ & $\begin{array}{l}\text { a. Membahas mengenai } \\
\text { cuaca } \\
\text { b. Membahas mengenai } \\
\text { alat tangkap } \\
\text { c. Membahas mengenai } \\
\text { kapal yang digunakan } \\
\text { d. Lokasi tangkapan } \\
\text { e. Permasalahan } \\
\text { keuangan dalam } \\
\text { keluarga } \\
\text { f. Pendidikan anak } \\
\text { g. Kendala dalam melaut }\end{array}$ & $\begin{array}{l}\text { Saluran } \\
\text { interpersonal } \\
\text { dalam: } \\
\text { 1. Percakapan } \\
\text { sehari-hari (di } \\
\text { rumah, di TPI, } \\
\text { di lokasi } \\
\text { melaut) } \\
\text { 2. Dalam } \\
\text { kegiatan sosial } \\
\text { 3. Silaturahmi }\end{array}$ & Nelay \\
\hline $\begin{array}{l}\text { Pedagang di } \\
\text { Tempat } \\
\text { Pelelangan } \\
\text { Ikan }\end{array}$ & $\begin{array}{l}\text { a. Mengenai penjualan } \\
\text { hasil tangkapan } \\
\text { b. Mengenai pendapatan } \\
\text { yang diperoleh } \\
\text { c. Bantuan modal usaha }\end{array}$ & $\begin{array}{l}\text { Saluran } \\
\text { Interpersonal }\end{array}$ & Nelayan \\
\hline
\end{tabular}

Sumber: Data Primer Diolah, 2014

Kaitannya dengan komunikasi interpersonal sebagai salah satu komunikasi yang berperan dalam menentukan tindakan nelayan dalam usaha perikanan tangkapnya untuk ketahanan pangan rumahtangga, terdapat beberapa teori yang dapat digunakan untuk mengkaji proses komunikasi yang terjadi, antara lain: konsep diri, teori atraksi interpersonal, dan sifat humanistik komunikasi antar pribadi (interpersonal).

Konsep diri melalui Jendela Johari, pengetahuan tentang diri seseorang akan meningkatkan komunikasi, dan pada saat yang sama, berkomunikasi dengan orang lain meningkatkan pengetahuan tentang diri orang tersebut (Rakhmat, 1999). Komunikasi interpersonal akan membuka diri seseorang 
untuk menerima pengalaman-pengalaman dan gagasan baru karena dengan seseorang mengetahui siapa dirinya dan lebih membuka siapa dirinya, maka hubungan yang terjalin akan lebih akrab, dan semakin banyak informasi yang diperoleh atau dengan kata lain komunikasi interpersonal akan semakin efektif.

Rakhmat (1999) menjelaskan bahwa bila individu-individu berinterkasi dan saling mempengaruhi, maka terjadilah (1) proses belajar yang meliputi aspek kognitif dan afektif (aspek berpikir dan aspek merasa), (2) proses penyampaian dan penerimaan lambing-lambang (komunikasi), dan (3) mekanisme penyesuaian diri seperti sosialisasi, identifikasi, dan sebagainya. Ketika nelayan berinteraksi dengan nelayan lainnya, maka terjadilah proses belajar. Dalam interaksi ini mereka saling bertukar pikiran dan saling merasakan apa yang sedang mereka hadapi, melalui percakapan sehari-hari mereka berusaha untuk menyelesaikan permasalahan yang mereka hadapi, misalnya bagaimana ketika mereka harus menghadapi musim badai yang akan datang.

Selain itu, komunikasi interpersonal lebih bersifat humanistik. Dalam komunikasi interpersonal ini nelayan lebih leluasa dalam membicarakan segala sesuatu, adanya persamaan masalah yang dihadapi atau dibicarakan, merasa adanya kesetaraan di antara mereka, tidak adanya perasaan saling mendominasi dalam pembicaraan.

\section{Komunikasi Kelompok}

Komunikasi kelompok merupakan pola komunikasi yang melibatkan beberapa partisipan komunikasi. Komunikasi kelompok dapat terjadi pada kelompok formal maupun kelompok informal yang ada dalam masyarakat nelayan di Kota Bengkulu, sebagai contoh komunikasi yang terjadi dalam pertemuan kelompok nelayan, percakapan dalam kelompok-kelompok ketetanggaan, dan dalam diskusi kelompok terkait kegiatan usaha perikanan tangkap, dan sebagainya.

Kelompok ketetanggaan di sini adalah ketetanggaan karena kedekatan tempat tinggal maupun ketetanggaan. Kelompok ini biasanya terdiri atas bapak-bapak dalam sebuah kelompok, sedangkan ibu-ibu juga mempunyai kelompok tersendiri. Sedangkan kelompok ketetanggaan nelayan adalah kumpulan orang-orang yang memiliki lokasi penangkapan ikan saling berdekatan.

1) Kelompok Nelayan

Kelompok nelayan merupakan himpunan nelayan-nelayan yang tergabung sebuah kelompok yang memiliki tujuan dan organisasi tertentu. Kelompok nelayan ini mengadakan pertemuan rutin setiap dua minggu sekali, yaitu tiap minggu siang pada minggu kedua. Unsur-unsur komunikasi dalam kelompok nelayan dalam memperbincangkan ketahanan pangan rumahtangga dapat dilihat pada Tabel 3 . 
Terdapat tiga arus informasi yang terjadi dalam komunikasi kelompok, yaitu: Pertama: Arus Informasi ke Bawah. Arus informasi ini terjadi ketika ketua kelompok nelayan berperan sebagai sumber informasi yang menyampaikan pesan secara langsung ke anggota dalam pertemuan kelompok. Hal-hal yang dibahas dalam kelompok nelayan biasanya tentang bantuan dari pemerintah untuk nelayan, mencari solusi yang diperlukan untuk mengatasi permasalahan yang dihadapi oleh nelayan, dan lokasi tangkapan baru yang potensial dijadikan lokasi penangkapan ikan. Berkaitan dengan ketahanan pangan ketua kelompok nelayan biasanya selalu mengingatkan nelayan akan persediaan pangannya dalam menghadapi musim badai yang tidak dapat diprediksi. Nelayan harus bisa mengatur penerimaan dari usaha perikanan tangkapnya agar memiliki cadangan pangan ketika nelayan tidak dapat melaut saat musim badai datang.

\section{Tabel 3. Unsur-unsur Komunikasi dalam Kelompok Nelayan di Kota} Bengkulu

\begin{tabular}{|c|c|c|c|}
\hline $\begin{array}{l}\text { Sumber } \\
\text { (Source) }\end{array}$ & Pesan (Message) & $\begin{array}{l}\text { Saluran } \\
\text { (Channel) }\end{array}$ & $\begin{array}{c}\text { Komunikan } \\
\text { (Receiver) }\end{array}$ \\
\hline $\begin{array}{l}\text { Ketua } \\
\text { kelompok }\end{array}$ & $\begin{array}{l}\text { a. Kendala dalam proses } \\
\text { penangkapan ikan } \\
\text { b. Bantuan dari Pemerintah } \\
\text { untuk nelayan } \\
\text { c. Bantuan modal yang } \\
\text { diperlukan } \\
\text { d. Lokasi tangkapan ikan } \\
\text { yang baru } \\
\text { e. Nelayan harus } \\
\text { mewaspadai musim } \\
\text { badai yang tidak } \\
\text { diprediksi }\end{array}$ & $\begin{array}{l}\text { Saluran } \\
\text { Interpersonal } \\
\text { dalam } \\
\text { pertemuan } \\
\text { kelompok }\end{array}$ & $\begin{array}{l}\text { Anggota } \\
\text { kelompok } \\
\text { nelayan }\end{array}$ \\
\hline $\begin{array}{l}\text { Anggota } \\
\text { kelompok }\end{array}$ & $\begin{array}{l}\text { a. Hasil tangkapan } \\
\text { b. Kebutuhan nelayan } \\
\text { dalam melaut } \\
\text { c. Alat tangkap } \\
\text { d. Harga jual ikan }\end{array}$ & $\begin{array}{l}\text { Saluran } \\
\text { interpersonal } \\
\text { dalam } \\
\text { pertemuan } \\
\text { kelompok }\end{array}$ & $\begin{array}{l}\text { Sesama } \\
\text { anggota } \\
\text { kelompok } \\
\text { nelayan }\end{array}$ \\
\hline
\end{tabular}

Sumber: Data Primer Diolah, 2014

Kedua: Arus Informasi ke Atas, dalam arus informasi ini terjadi ketika anggota biasanya menanyakan kembali informasi yang disampaikan ketua kelompok nelayan atau yang berkaitan dengan adanya informasi terkait usaha perikanan tangkap seperti bantuan permodalan dari pemerintah, dan lain-lain. Ketiga: Arus Informasi Lateral, yang berlangsung antar anggota. Komunikasi lateral ini dapat terjadi di sela-sela kegiatan pertemuan, di luar pertemuan 
ataupun ketika di laut ketika mereka menunggu hasil tangkapan. Nelayan kapal kecil ini memiliki lokasi penangkapan ikan yang saling berdekatan sehingga memungkinkan untuk mereka melakukan komunikasi sambil menunggu hasil tangkapannya. Hal-hal yang dibicarakan masih terkait dengan usaha perikanan tangkapnya, antara lain harga jual ikan yang ditangkap, hasil tangkapan, kebutuhan yang diperlukan selama melaut, dan peralatan yang digunakan untuk menangkap ikan.

2) Kelompok Ketetanggaan Bapak-bapak

Kelompok ketetanggaan bapak-bapak ini biasanya berkumpul, di salah satu rumah warga, di Tempat Pelelangan Ikan (TPI) Pulau Baai, maupun di lingkungan rumah mereka pada malam hari. Anggota dalam kelompok ini biasanya berjumlah enam sampai dengan sepuluh orang dengan karakteristik yang relatif homogen dalam arti memiliki tingkat pendidikan yang sama, pekerjaan yang sama (nelayan) dan usia yang relatif sebaya. Kaitannya dengan topik perbincangan seputar usaha perikanan tangkapnya untuk ketahanan pangan rumahtangga mereka dapat dilihat pada Tabel 4.

Tabel 4. Unsur-unsur Komunikasi dan Komunikasi Kelompok dalam Ketetanggaan Bapak-bapak

\begin{tabular}{llll}
\hline $\begin{array}{c}\text { Sumber } \\
\text { (Source) }\end{array}$ & \multicolumn{1}{c}{ Pesan (Message) } & \multicolumn{1}{c}{$\begin{array}{c}\text { Saluran } \\
\text { (Channel) }\end{array}$} & $\begin{array}{c}\text { Komunikan } \\
\text { (Receiver) }\end{array}$ \\
\hline Sesama & a. Masalah penerimaan & $\begin{array}{l}\text { Saluran } \\
\text { interpersonal } \\
\text { Bapak-bapak }\end{array}$ & $\begin{array}{l}\text { Sesama Bapak- } \\
\text { bapak }\end{array}$ \\
& $\begin{array}{l}\text { b. Harga sembako } \\
\text { dalam bentuk }\end{array}$ & \\
& $\begin{array}{l}\text { c. Pendidikan anak- } \\
\text { anak }\end{array}$ & $\begin{array}{l}\text { percakapan } \\
\text { langsung }\end{array}$ & \\
& d. Musim badai & & \\
& e. Kebutuhan & & \\
& rumahtangga & & \\
& f. Membahas isu dalam & & \\
& masyarakat & & \\
\hline
\end{tabular}

Sumber: Data Primer Diolah, 2014

Dalam kelompok ketetanggaan yang terdiri dari Bapak-bapak ini terjadi komunikasi dimana sumber (komunikator) adalah mereka yang tergabung dalam kelompok tersebut. Semua anggotanya dapat berperan sebagai sumber informasi maupun penerima informasi (komunikan) secara bergantian. Dalam komunikasi kelompok ini arus komunikasi bersifat lateral, semua yang tergabung dalam kelompok mempunyai kedudukan sejajar dapat menyampaikan informasi. Pesan atau informasi terkait usaha perikanan tangkap pada nelayan kapal kecil untuk ketahanan pangan rumahtangga mereka yang diperbincangkan antara lain kondisi kapal, jaring, dan hasil tangkapan nelayan terutama ketika akan menghadapi musim badai. 
Pertemuan yang dilakukan setiap malam hari merupakan media atau saluran yang digunakan kelompok ketetanggaan ini untuk memperbincangkan usaha perikanan tangkapnya terkait ketahanan pangan rumahtangga nelayan di Kota Bengkulu.

3) Kelompok Ketetanggaan Ibu-ibu

Kelompok ketetanggaan ibu-ibu merupakan kelompok yang terdiri dari ibu-ibu yang rumahnya berdekatan. Keanggotaan dari kelompok ini relatif tetap yang terdiri dari lima sampai tujuh orang. Karakteristik dari anggota kelompok ini secara tingkat ekonomi dan pendidikan hampir sama namun dari segi usia lebih bervariatif dari ibu-ibu yang masih muda sampai dengan ibuibu yang sudah berusia lanjut. Pola komunikasi kelompok ketetanggaan ibuibu jika dijabarkan ke dalam unsur-unsur komunikasi seperti tertera dalam Tabel 5.

Tabel 5. Unsur-unsur Komunikasi dan Komunikasi Kelompok dalam Ketetanggaan Ibu-ibu

\begin{tabular}{|c|c|c|c|}
\hline $\begin{array}{l}\text { Sumber } \\
\text { (Source) }\end{array}$ & Pesan (Message) & $\begin{array}{l}\text { Saluran } \\
\text { (Channel) }\end{array}$ & $\begin{array}{c}\text { Komunikan } \\
\text { (Receiver) }\end{array}$ \\
\hline $\begin{array}{l}\text { Sesama Ibu- } \\
\text { Ibu }\end{array}$ & $\begin{array}{l}\text { a. Kebutuhan hidup sehari- } \\
\text { hari } \\
\text { b. Harga sembako } \\
\text { c. Pengeluaran } \\
\text { rumahtangga } \\
\text { d. Penghasilan tambahan } \\
\text { e. Masalah internal } \\
\text { keluarga } \\
\text { f. Penghasilan suami } \\
\text { g. Pendidikan anak-anak }\end{array}$ & $\begin{array}{l}\text { Saluran } \\
\text { interpersonal } \\
\text { dalam bentuk } \\
\text { percakapan } \\
\text { langsung yang } \\
\text { disampaikan } \\
\text { dalam } \\
\text { kegiatan } \\
\text { berkumpul }\end{array}$ & $\begin{array}{l}\text { Sesama Ibu- } \\
\text { ibu }\end{array}$ \\
\hline
\end{tabular}

Sumber: Data Primer Diolah, 2014.

Setiap pertemuan, ketika berkunjung dan berkumpul di salah satu rumah tetangga merupakan saluran interpersonal bagi kelompok ibu-ibu yang berdekatan tempat tinggal ini. Mereka selalu terlibat dalam pembicaraan. Setiap anggota dapat berperan sebagai komunikator (sumber informasi) maupun sebagai komunikan (penerima informasi) secara bergantian (timbal balik). Dalam pembicaraan ini mereka lebih banyak berbicara mengenai kondisi rumahtangga dan kondisi pangan rumahtangganya serta saling membandingkan pendapatan rumahtangga mereka. Sebagai contoh, diskusi tentang cadangan beras mereka yang telah menipis dan rasa pesimis akan pendapatan rumahtangganya yang akan semakin menurun dalam menghadapi musim badai. Dari perbincangan tersebut, muncul keinginan mereka untuk mencari penghasilan tambahan agar dapat meningkatkan pendapatan 
rumahtangganya dan sebagai cadangan ketika suami mereka tidak dapat melaut selama musim badai terjadi.

Komunikasi kelompok yang terjadi dalam kelompok-kelompok informal, persamaan latar belakang maka orang-orang yang terlibat dalam kelompok-kelompok informal ini akan mempengaruhi keefektifan jalannya komunikasi. Kesamaan karakteristik ini disebut homofili. Rogers (1995) mendefinisikan homofili sebagai suatu derajat di mana dua atau lebih individu yang berinteraksi serupa dalam atribut-atribut tertentu, misalnya kepercayaan, pendidikan, status sosial, dan lain sebagainya. Dalam satu situasi yang bebas, ketika seorang individu dapat berinteraksi dengan salah seorang dari sejumlah individu lainnya, ada satu kecenderungan yang kuat untuk memilih seseorang yang paling serupa. Keakraban secara fisik dan sosial ini menjadikan komunikasi homophilous menjadi lebih mungkin.Komunikasi seperti ini juga lebih memungkinkan menjadi efektif dan menguntungkan.Selain adanya homofili yang menyebabkan semakin efektifnya komuniekasi yang berlangsung pada kelompok-kelompok informal. Rakhmat (1999) menjelaskan bahwa kelompok berpengaruh terhadap perilaku komunikasi.

Perilaku komunikasi tersebut meliputi konformitas, fasilitasi sosial, dan polarisasi. Konformitas merupakan kecenderungan para anggota untuk mengatakan dan melakukan hal yang sama. Menurut Rakhmat (1999), menyebut fasilitasi sosial sebagai teori "drive" dimana kehadiran orang lain dianggap menimbulkan efek pembangkit energi pada perilaku individu. Energi yang meningkat akan mempertinggi kemungkinan dikeluarkannya respons yang dominan. Rakhmat (1999) juga menjabarkan teori polarisasi yang dikenal dengan geseran resiko (risky shift), yang menyatakan bahwa orang cenderung membuat keputusan yang lebih berani ketika berada dalam kelompok daripada ketika mereka sendirian. Karena dalam kelompok, individu dapat berbagi tanggung jawab dengan individu yang lain sehingga resiko kegagalan juga ditanggung bersama. Dalam pelaksanaan usaha perikanan tangkapnya, nelayan mengadakan diskusi dengan kelompok nelayannya. Melalui diskusi tersebut mereka berusaha untuk menyelesaikan permasalahan yang mereka hadapi bersama-sama. Kecenderungan untuk melakukan sesuatu hal bersama-sama di antara nelayan juga merupakan konformitas dalam kelompok.

\section{Komunikasi Massa}

Selain komunikasi interpersonal dan komunikasi kelompok, ditemukan pula komunikasi massa. Komunikasi massa merupakan komunikasi dengan menggunakan media massa seperti radio dan televisi. Kaitannya dengan pesan ketahanan pangan, nelayan kurang mengakses informasi tersebut dari kedua media ini. Terdapat beberapa alasan yang disampaikan oleh nelayan mengenai 
kurangnya mereka mengakses media massa radio dan televisi adalah sebagai berikut.

a. Terlalu letih dengan pekerjaannya membuat malas untuk mengakses media massa tersebut dan memilih untuk beristirahat.

b. Televisi lebih banyak dikuasai oleh anggota keluarga lain (anak-anak) sehingga acara yang ditonton atau diikuti sesuai dengan selera mereka.

c. Jika ada waktu menonton, acara yang diakses sebatas untuk kepentingan hiburan dan mengetahui peristiwa terkini.

d. Tidak mengetahui waktu dan stasiun televisi atau radio yang menyajikan informasi tentang perikanan tangkap di Kota Bengkulu dan sekitarnya.

e. Berita yang disampaikan tidak sesuai dengan kondisi perikanan tangkap yang mereka hadapi.

Kurang efektifnya komunikasi massa dalam menyampaikan pesan terkait usaha perikanan tangkap dan ketahanan pangan rumahtangga, hal ini disebabkan adanya beberapa hal yang membedakan komunikasi massa dengan komunikasi interpersonal. Rakhmat (1999) mengidentifikasi beberapa hal yang membedakan komunikasi massa dengan komunikasi interpersonal diantaranya adalah pada pengendalian arus informasi. Pada penelitian ini, nelayan kurang tertarik mengakses radio dan televisi karena hanya menerima informasi yang disampaikan oleh sumber tanpa bisa turut mengendalikan mana pesan yang sesuai untuknya, misalnya yang dibahas adalah usaha perikanan tangkap dalam skala besar saja tapi informasi usaha perikanan tangkap untuk nelayan kapal kecil hanya dibahas sedikit saja dan sering tidak mengarah pada permasalahan yang dihadapi oleh nelayan. Oleh karena itu, dalam hal ini pengaksesan media massa hanya sebatas untuk mendapatkan berita terkini dan sebagai hiburan.

\section{SIMPULAN DAN SARAN}

\section{Simpulan}

Hasil penelitian menunjukkan terdapat dua pola komunikasi nelayan dalam memperbincangkan permasalahan ketahanan pangan rumahtangganya, yaitu pola komunikasi interpersonal dan pola komunikasi kelompok. Pola komunikasi interpersonal lebih banyak melibatkan sumber informasi dari nelayan lain. Pesan yang banyak diperbincangkan adalah segala sesuatu yang berkaitan dengan usaha perikanan tangkapnya. Di antara komunikasi kelompok yang ada, diskusi dalam kelompok nelayan memiliki pengaruh terhadap tindakan nelayan dalam menjalankan usaha perikanan tangkapnya. Kemajuan dalam usaha perikanan tangkap ini dapat meningkatkan penerimaan nelayan yang juga akan berdampak pada pemenuhan kebutuhan pangan dalam keluarganya. 


\section{Saran}

Nelayan sebaiknya mengatur dan mempersiapkan dengan baik cadangan pendapatan rumahtangganya agar pemenuhan kebutuhan pangan rumahtangganya masih dapat terpenuhi dengan baik ketika musim badai datang. Karena pada musim badai, nelayan tidak bisa menjalankan usaha perikanan tangkapnya sehingga penerimaan tidak ada. Musim badai tidak diprediksi kapan datangnya dan terjadi berapa lama, sehingga sangat diperlukan nelayan mengatur penerimaan rumahtangganya dengan baik.

\section{DAFTAR PUSTAKA}

Arumsari, Vini dan Wulandari Dwi Etika Rini. 2007. Peran Wanita Tani dalam Mewujudkan Ketahanan Pangan pada Tingkat Rumahtangga di Kabupaten Sleman Daerah Istimewa Yogyakarta. Jurnal Ekonomi Pembangunan Vol. 13 No.1, April 2008 Hal.: 71-82.

(http://journal.uii.ac.id/index.php/JEP/article/viewFile/52/150). Diakses Tanggal 23 Juni 2014.

Kusnadi, A. 2000. Konflik Sosial Nelayan, Kemiskinan dan Perebutan Sumberdaya Perikanan. Yogyakarta.

Rakhmat, Jalaluddin. 1999. Psikologi Komunikasi. Edisi Revisi. Bandung: PT Remaja Rosdakarya.

Rogers, E.M. 1995. Diffusion of Innovation. $4^{\text {th }}$ Edition. New York: The Free Express. Saliem, Handewi Purwanti, Adreng Purwoto, Gatoet Sroe Hardono, Tri Bastuti Purwantini, Yana Supriyatna, Yuni Marisa, dan Waluyo. 2005. Manajemen Ketahanan Pangan Era Otonomi Daerah dan Perum BULOG. Pusat Analisis Sosial Ekonomi dan Kebijakan Pertanian Badan Penelitian dan Pengembangan Pertanian Departemen Pertanian. Jakarta.

Satria, A. 2002. Pengantar Sosiologi Masyarakat Pesisir. Jakarta: Cidesindo.

Suryana, Achmad. 2004. Kapita Selekta Evolusi Pemikiran Kebijakan Ketahanan Pangan. Fakultas Ekonomi UGM. Yogyakarta.

Tanziha I. 2005. Analisis Peubah Konsumsi Pangan dan Sosial Ekonomi rumahtangga untuk Menentukan Determinan dan Indikator Kelaparan. Disertasi Program Pasca Sarjana Institut Pertanian Bogor. Bogor. Tidak Dipublikasikan.

Widodo dan Mukhtar. 2000. Konstruksi ke Arah Penelitian Deskriptif. Yogyakarta: Avyrouz. 